\title{
Impact of index card match method on the knowledge and attitudes about leucorrhoea among adolescent girls
}

\author{
Yuanita Syaiful, ${ }^{1}$ Lilis Fatmawati, ${ }^{1 *}$ Siti Nur Qomariah, ${ }^{2}$ Mafrukhatul Firdani ${ }^{3}$ \\ ${ }^{1}$ Department of Maternity Nursing, Faculty of Health Science, Gresik University, Gresik, Indonesia \\ ${ }^{2}$ Department of Medical Surgical Nursing, Faculty of Health Science, Gresik University, Gresik, Indonesia \\ ${ }^{3}$ Nursing Science Program, Faculty of Health Science, Gresik University, Gresik, Indonesia
}

SUBMITTED: 5 December 2020 REVISED: 17 September 2021 ACCEPTED: 4 October 2021

KEYWORDS

Adolescent girls

Attitude

Index card match

Knowledge

Leucorrhoea
ABSTRACT Leucorrhoea is a reproductive health problem that often appears in adolescents. Girls between the ages of 12-16 are at high risk of leucorrhoea. The Index Card Match (ICM) method is recognized as an effective preventive effort of the adolescent health education. This research aimed to discover the impact of the ICM method on the knowledge and attitudes about leucorrhoea among adolescent girls and prove the ICM method's effectivity between the treatment and control groups. This study used a quasi-experimental design with a pre-post test and control group. The population of this research was 40 adolescent girls. The sample included as many as 32 respondents using purposive sampling who were then divided into 2 groups: treatment and control, with each group consisting of 16 respondents. The independent variable was health education using the ICM method. The dependent variables were knowledge and attitude. The instruments used a questionnaire of knowledge and attitude, index card match, leaflet, and event activity unit. Data analysis used a paired T-test and the independent T-test with the significance set as $p<0.05$. The results of the paired sample T-test in the treatment group obtained the value of $p=0.000(p<0.05)$, which means that after the ICM method there was significant improvement in the knowledge about leucorrhoea among the adolescent girls. The independent $\mathrm{T}$ test obtained $p$ value = $0.000(p<0.05)$, which indicated there was significant difference in knowledge between the treatment and control groups. The paired T test in the treatment group obtained the value of $p=0.000(p<0.05)$, which means that after the ICM method there was significant change in the attitudes about leucorrhoea among the adolescent girls. The independent $\mathrm{T}$ test obtained the value of $p=0.000(p<0.05)$, which indicated there was a significant difference in post-test attitudes between the treatment and control groups. Health education with the index card match method was one of the effective learning methods that could be accepted well by the respondents. As a result, the respondents could improve their learning about leucorrhoea.

(c) The Journal 2021. This article is distributed under a Creative Commons Attribution-ShareAlike 4.0 International license.

\section{Introduction}

Adolescence is a period of transition from childhood to adulthood. During this period, various changes occur, including hormonal, physical, psychological and social changes. Adolescents are one part of the population who are at risk of developing vaginal discharge that needs special attention. ${ }^{1}$ Leucorrhoea is a reproductive health problem that often appears in adolescents which is an early symptom of cervical

\footnotetext{
*Correspondence: Iilisfatmawati13@gmail.com

Department of Maternity Nursing, Faculty of Health Science, Universitas Gresik, Jl. Arif Rahman Hakim Gresik No. 2B Gresik, JawaTimur 61111, Indonesia
}

cancer. Symptoms that are more often felt by women may not be recognized at a younger age, especially in adolescents. ${ }^{2}$ Symptoms of vaginal discharge are also experienced by unmarried women or girls in the early adolescent category, namely young girls aged 12-16 years, which includes about $31.8 \%$. This shows that adolescent girls are more at risk of developing vaginal discharge. ${ }^{3}$

Many women experience vaginal discharge, but this is often neglected because they think it is common for a woman, since vaginal discharge is a common complaint, especially among women in Asia ${ }^{4}$. Research found that $75 \%$ of women in the 
world have experienced vaginal discharge that accompanies vulvovaginal candidiasis at least once in their life, and $45 \%$ of them have had it 2 or more times. In Indonesia around $90 \%$ of women have the potential to experience vaginal discharge because Indonesia is an area that has a tropical climate, so the fungus can easily grow.

Research in East Java also showed $75 \%$ of adolescents suffer from vaginal discharge at least once in their lifetime. ${ }^{5}$ One of the most dangerous effects is if vaginal discharge is not handled properly, it will cause cervical cancer. The number of new patients with cervical cancer in East Java in 2012 was 2,940 and this number increased in 2013 by 3,971 people. ${ }^{5}$ Meanwhile, in Gresik, East Java, $11.60 \%$ had positive IVA results from the CBE clinical examination in the year 2019.

According to research conducted by Bloom, the behavior based on knowledge will be more lasting than behavior involving the lack of knowledge. However, the effect of health education on people's own knowledge and attitudes is still unclear. ${ }^{6}$ Prevention efforts also require a good knowledge base because health behaviors based on knowledge last longer than behaviors that are not based on knowledge. ${ }^{7}$ According to Wisnatu and Reni the cause of vaginal discharge is due to the lack of knowledge of women in Indonesia about vaginal discharge so that they consider vaginal discharge as a common and trivial occurrence. In addition, shame when experiencing vaginal discharge often makes women reluctant to consult health workers. ${ }^{8}$

Adolescents need assistance to receive the right reproductive health information, since limited knowledge about reproductive health can trigger unhealthy behavior in adolescents. ${ }^{3}$ In this regard, the role of health workers can provide socialization through health education, especially about vaginal discharge so that they can improve their efforts in handling this health concern by giving attention to which approach is properly done, which one is wrong if done, and how to do the proper treatment. ${ }^{7}$ According to Silberman, one way to repeat learning materials can be using the Index Card Match (ICM) method which is an active and fun way of learning. ${ }^{9}$ Learning in this way allows participants to pair up and play quizzes with other participants. Active learning activities include various ways to make participants active from the very beginning of the learning activity. This strategy aims to increase participant activeness in reviewing the material presented by the presenter. This is in accordance with research conducted in 2010 by Ayesha which states that the Index Card Match method is effective in increasing adolescent knowledge, attitudes, and (psychomotor) behaviors about personal hygiene during menstruation. ${ }^{10}$ The use of the Index Card Match method strategy is expected to lead to interesting and fun health education activities, help in understanding difficult concepts and aid in increasing memory in the long term. This research aimed to determine: 1 ) the impact of the ICM method on the knowledge and attitude of adolescent girls about leucorrhoea, and 2 ) prove the ICM's effectivity between the treatment and control groups.

\section{Method}

This study used a quasi-experimental method with the design of a control group and pre-post test. Population of this study was 40 adolescent girls in Babaksari Gresik. The sampling technique used in this study was purposive sampling, which is a sample determination technique by selecting a sample among the population according to the research purposes. Samples were taken according to the following inclusion criteria: age 12-16 years old and willing to be a respondent. The sample size was 32 respondents, divided into 2 groups with 16 respondents as the control group, and 16 respondents as the treatment group. Each respondent was observed before the intervention, then observed again after the intervention and the control group was observed pre-post without intervention.

In this study, the instruments used were the Leucorrhoea SAP (Extension Program), knowledge questionnaires have been validity $(r>0.300)$ and reliability $(a>0.600)$ tested, and attitude questionnaires have been tested with validity result of $100 \%$ and reliability ( $a>0.744$ ), in addition to leucorrhoea leaflets, and the ICM about Leucorrhoea. For the treatment group, each participant underwent testing of their pre education data of knowledge and 
attitude, then education for 40 minutes every day for two days, and then the ICM method for post test data of knowledge and attitude. The control group underwent the pretest and posttest after five days of education about leucorrhoea without the ICM method.

Scoring of knowledge gave 1 point, if answer was correct and 0 point for the wrong answer. Sum of the answers was divided with highest score then multiplied by $100 \%$. Criteria of the knowledge used the following scale: good (76-100\%), sufficient (56$75 \%)$, and insufficient ( $<56 \%)$. Attitude scoring was positive if score $\geq$ mean, or negative if score $<$ mean. The researchers tested the data using paired simple T-tests because the research data had normal distribution which can be seen in the normality test table with $p$ sig $>0.05$, and was done to determine the average difference in results between pretest and posttest. The independent $T$ test was used to compare the results between the treatment and control groups with $p$ sig $>0.05$.

The ethical clearance of this study was established by decree number: 188/117/437.114.20/2020 from KEPK Health Science Faculty Gresik University. The ethical principles applied in this study included participants who were given adequate information and who provided informed consent before data collection. All respondents' data were collected and recorded with confidentiality by only using their initials.

\section{Result}

\subsection{Characteristics of Respondents}

In the treatment group (Table 1), most of the respondents were 16 years old, with as many as 5 adolescents (31.25\%) and in the control group, most of the respondents were 12 years old, as many as 6 adolescents (37.5\%). At the education level, it was shown most of the respondents had the same last education at Senior High School, with as many as 10 adolescents $(62.5 \%)$ in the treatment group and in the control group as many as 8 adolescents $(50 \%)$. While in the treatment group, most of the respondents received information from the mass media, as many

Table 1. Characteristics of respondents.

\begin{tabular}{|c|c|c|c|c|c|}
\hline \multirow[t]{2}{*}{ Characteristic } & \multirow[t]{2}{*}{ Criteria } & \multicolumn{2}{|c|}{ Treatment } & \multicolumn{2}{|c|}{ Control } \\
\hline & & $\mathbf{N}$ & $\%$ & $\mathbf{N}$ & $\%$ \\
\hline \multirow{5}{*}{ Age } & 12 years & 1 & 6.25 & 6 & 37.5 \\
\hline & 13 years & 4 & 25 & 0 & 0 \\
\hline & 14 years & 2 & 12.5 & 1 & 6.25 \\
\hline & 15 years & 4 & 25 & 5 & 31.25 \\
\hline & 16 years & 5 & 31.25 & 4 & 12.5 \\
\hline \multirow[t]{3}{*}{ Level of Education } & Elementary & 1 & 6.25 & 4 & 25 \\
\hline & Junior High School & 5 & 31.2 & 4 & 25 \\
\hline & Senior High School & 10 & 62.5 & 8 & 50 \\
\hline \multirow[t]{4}{*}{ Source of information } & Parents & 5 & 31.2 & 8 & 50 \\
\hline & Teacher & 3 & 18.8 & 2 & 12.5 \\
\hline & Mass media & 6 & 37.5 & 6 & 37.5 \\
\hline & Health Workers & 2 & 12.5 & 0 & 0 \\
\hline \multirow[t]{4}{*}{ Sign and Symptom of Leucorrhoea } & Nothing & 8 & 50 & 5 & 31.25 \\
\hline & Bad Smell & 5 & 31.2 & 6 & 37.5 \\
\hline & Itchy & 3 & 18.8 & 4 & 25 \\
\hline & Pain when urinary & 0 & 0 & 1 & 6.25 \\
\hline \multirow[t]{3}{*}{ Vaginal Cleanser } & Use & 0 & 0 & 6 & 37.5 \\
\hline & Not Use & 13 & 81.2 & 7 & 43.75 \\
\hline & Rarely Use & 3 & 18.8 & 3 & 18.75 \\
\hline \multirow{3}{*}{$\begin{array}{l}\text { Action if there is abnormal vaginal } \\
\text { discharge }\end{array}$} & None & 9 & 56.2 & 10 & 62.5 \\
\hline & Check with a health worker & 4 & 25 & 0 & 0 \\
\hline & Self-medicating & 3 & 18.8 & 6 & 37.5 \\
\hline
\end{tabular}


as 6 adolescents (37.5\%), in the control group, half of the respondents received information from their parents, as many as 8 adolescents (50\%). In the treatment group, half of them had no signs and symptoms when experiencing vaginal discharge, as many as 8 adolescents (50\%), while in the control group most of the respondents experienced signs and symptoms of bad smell when experiencing vaginal discharge, as many as 6 adolescents (37.5\%). In the treatment and control groups, most of the respondents had the same characteristics and did not use feminine hygiene/ vaginal cleanser, as many as 13 adolescents (81.2\%) and in the control group, as many as 7 adolescents (43.75\%). Both groups also had the same characteristics, with most of the respondents choosing to not do anything when there was abnormal vaginal discharge, with as many as 9 adolescents (56.2\%) and in the control group as many as 10 adolescents (62.5\%).

\subsection{The effect of the ICM method on adolescent girls' knowledge about leucorrhoea}

Based on Table 2, the results of knowledge about leucorrhoea in the treatment group in the pre-test were mostly insufficient knowledge with as many as 8 adolescents (50\%) and in the post-test results were mostly good knowledge with as many as 14 adolescents (87.5\%). Meanwhile in the control group, the results of pre-test were mostly insufficient knowledge with as many as 9 adolescent (56.25\%) and in the post-test results were mostly insufficient knowledge with as many as 8 adolescents (50\%).

The results of data analysis using the paired T-tests in the treatment group obtained a value of $p=0.000$ which means there was a significant impact from the ICM method on the adolescent girls' knowledge about leucorrhoea. The result of the independent T-test between the treatment and control groups obtained value of $p=0.000$ which means there was a significant difference between the two groups in the adolescent girls' knowledge about leucorrhoea.

\subsection{The ICM method's effect on the adolescent girls' attitudes about leucorrhoea}

Based on the Table 3, it was found that the pre-test attitudes of adolescents about leucorrhoea, in the treatment group mostly had positive attitudes with as many as 9 adolescents (56.25\%), while post-test entirely had positive attitude with as many as 16 adolescents (100\%). In the control group, pre-test indicated mostly negative attitudes with as many as 9 adolescents (56.25\%), while the post-test results obtained indicated that almost all had positive attitude with as many as 15 adolescents (93.75\%).

The results of data analysis using the paired T-test in the treatment group obtained a value of $p=0.000$, which means there was a significant impact from the ICM method on the adolescent girls' attitudes about leucorrhoea. The results of independent T-test between the treatment and control groups obtained value of $p=0.000$, which means there was a significant difference between the two groups in the adolescent girls' attitudes about leucorrhoea.

\section{Discussion}

\subsection{The Effect of the ICM Method on Adolescent Girls' Knowledge About Leucorrhoea}

The results of the independent simple $T$ tests for the two groups obtained $p$ value $=0.000(p<0.05)$, indicating there was a significant difference in knowledge between the treatment and control groups. According to Notoadmojoto, an important step in health education is to make information tailored to target populations including media selection, intensity and duration of information delivery. Delivery of information is also influenced by the methods and media used in delivering information so that it can have a significant effect on increasing knowledge. ${ }^{12}$ Techniques and methods of conveying information are important factors that support the success of information sharing.

Health education using the ICM method can increase knowledge. According to Yanti and Karani, ${ }^{13}$ because this method is cooperative learning, using this method in the health education process can provide quality interactions among participants to give participants an opportunity to share and exchange their opinions or ideas so that more help participants understand the material provided. This research is in line with research conducted in 2009 by Pinki that showed the results with a significance 
Table 2. Results of knowledge about leucorrhoea

\begin{tabular}{|c|c|c|c|c|c|c|c|c|}
\hline \multirow{3}{*}{ Category } & \multicolumn{4}{|c|}{ Treatment } & \multicolumn{4}{|c|}{ Control } \\
\hline & \multicolumn{2}{|c|}{ Pre-test } & \multicolumn{2}{|c|}{ Post-test } & \multicolumn{2}{|c|}{ Pre-test } & \multicolumn{2}{|c|}{ Post test } \\
\hline & $n$ & $\%$ & $n$ & $\%$ & $\mathbf{N}$ & $\%$ & $n$ & $\%$ \\
\hline Good & 1 & 6.25 & 14 & 87.5 & 0 & 0 & 2 & 12.5 \\
\hline Sufficient & 7 & 43.75 & 2 & 12.5 & 7 & 43.75 & 6 & 37.5 \\
\hline Insufficient & 8 & 50 & 0 & 0 & 9 & 56.25 & 8 & 50 \\
\hline Total & 16 & 100 & 16 & 100 & 16 & 100 & 16 & 100 \\
\hline Paired T test & \multicolumn{4}{|c|}{$P=0.000$} & \multicolumn{4}{|c|}{$P=0.060$} \\
\hline Independent $\mathrm{T}$ test & \multicolumn{8}{|c|}{$P=0.000$} \\
\hline
\end{tabular}

Table 3. Attitudes of adolescents about leucorrhoea

\begin{tabular}{lllllllll}
\hline \multirow{2}{*}{ Category } & \multicolumn{1}{l}{ Treatment } & \multicolumn{3}{l}{ Control } \\
\cline { 2 - 9 } & Pre-test & Post-test & Pre-test & \multicolumn{2}{c}{ Post test } \\
\cline { 2 - 9 } & $\mathbf{N}$ & $\mathbf{\%}$ & $\mathbf{N}$ & $\mathbf{\%}$ & $\mathbf{n}$ & $\mathbf{\%}$ & $\mathbf{n}$ & \% \\
\hline Positive & 9 & 56.25 & 16 & 100 & 7 & 43.75 & 15 & 93.75 \\
\hline Negative & 7 & 43.75 & 0 & 0 & 9 & 56.25 & 1 & 6.25 \\
\hline Total & 16 & 100 & 16 & 100 & 16 & 100 & 16 & 100 \\
\hline Paired sample T test & $\mathrm{P}=0.000$ & & & $\mathrm{P}=0.011$ & & \\
\hline Independent Sample T test & $\mathrm{P}=0.000$ & & & & & \\
\hline
\end{tabular}

value of $p=0.000(p<0.05)$ with the conclusion that there is a significant effect of the ICM method in health education about high-risk pregnancy on the knowledge of pregnant women in Gonilan village. ${ }^{14}$ According to Silbermanin, learning through the ICM method is effective because, being mentally active is more desirable than being physically active. ${ }^{9}$ Therefore, the activity of frequently asking questions, questioning other people's ideas, and expressing ideas are signs of mental activity.

\subsection{The effect of the ICM method on adolescent girls' attitudes about leucorrhoea}

The results of the independent simple T tests for the two groups obtained the value of $p=0.000(p<0.05)$, which means there was a significant difference in post-test attitudes between the treatment and control groups.

The ICM method has an influence on the attitude of adolescent women about vaginal discharge. One study used a different method regarding the object of attitudes which resulted in inconsistency in respondents' attitudes, while the ICM method will try to realign responses so that a new consistency of attitude is formed. ${ }^{10}$ According to Anik, the attitude structure consists of three components that support each other, namely the cognitive, affective, and conative components. ${ }^{15}$

The cognitive component contains a person's belief in the object of the attitude. Once that belief has been formed, it will become the basis for a person's knowledge of what the expects from a certain object. According to Azwar, as quoted in Hernawan and Ermulyadi, a person who believes that the actions to be taken will have a positive impact, they will be inclined to take these actions. ${ }^{16}$

Likewise, if someone believes the action will have a negative impact, they will refuse to take the action. This is called behavior belief. In addition to personal belief (behavior belief), group belief also determines one's actions. If the person believes that their action will be approved by their group or social environment, then they will do it. Conversely, if they believe that their social environment will not support then no action will be taken. To convince someone of an objective, we need a complex approach, which means that it must be adjusted to several factors that influence these changes.

According to Anik, social attitudes are formed 
by the presence of social interactions. ${ }^{15}$ In these social interactions, individuals form certain patterns of attitudes towards the psychological objects they face. In teaching attitudes, each factor individually or collectively must be manipulated in order to form the positive attitude that is the desired outcome.

One of the most influential factors in shaping the attitude is the emotional factor or feeling in accepting an attitude object. According to Silbermanin, in the ICM method, each individual is asked to find a solution to the problem, namely by looking for pairs of question and answer cards so that the learning atmosphere becomes more enjoyable. ${ }^{9}$

In accordance with the precede-procedural theory, providing proper health education can manipulate predisposing factors, one of which is individual attitudes. This means the provision of appropriate health education can affect someone emotionally, and can increase individual knowledge which can lead to positive attitude changes. This is in line with research conducted in 2010 by Ayesha, ${ }^{10}$ showing the results of $p=0.000(p<0.05)$ with the conclusion that the ICM method is more effective in increasing adolescents' knowledge, attitudes, and (psychomotor) behavior about personal hygiene during menstruation compared to the lecture method. ${ }^{10}$

The advantage of this research is that health education with this method can be applied as an approach to young women, especially in rural areas who still lack information and still consider taboos to talk about the reproductive system, because the ICM method is a fun method that allows participants to be more active and this makes it easy to understand new information. Also, they can practice this method so that it is more varied as a material for delivering health promotion to the community.

Limitations in this research were: 1) The research process was conducted door-to-door due to limitations during the pandemic and the prohibition on gathering which resulted in taking a long time; 2) Respondents still seemed embarrassed when asking questions and must be stimulated first to be active during the ICM game; and finally, 3) The study was only conducted in the area of the village of Babaksari Sari Dukun Gresik so the results cannot be generalized.

\section{Conclusions}

There was a significant change from before and after the ICM method was applied to adolescent girls' knowledge about leucorrhoea. Also, there was a significant change from before and after the ICM method in adolescent girls' attitudes about leucorrhoea.

The ICM method is a fun method that allows participants to be more active and easier to understand information. The ICM method health promotion was proven to be more effective in increasing adolescent girls' knowledge and attitudes about leucorrhoea between the treatment group and control group.

\section{Acknowledgment}

Thanks to the Babaksari Village Head, Dukun Gresik, also to the respondents, especially the adolescent girls, and the team who supported the success of this research.

\section{Conflict of interests}

Authors declare no potential conflict of interests.

\section{References}

1. Kusmiran. Kesehatan Reproduksi Remaja dan Wanita. 2020. Jakarta: Salemba Medika.

2. Sulistyaningsih. Metode Penelitian Kebidanan Kualitatif Kuantitatif. 2011. Yogyakarta: Graha IImu.

3. Nurhayati, Annisa. Hubungan Pengetahuan, Sikap, Perilaku Vaginal Hygine terhadap Kejadian Keputihan Patologis pada Remaja Putri Usia 13-17 Tahun Di Daerah Pondok Cabe Ilir. Skripsi. Jakarta: Universitas Islam Negeri, Syarif Hidayatullah; 2013.

4. Martin R, Koniak G. Keperawatan Maternitas Kesehatan Wanita, Bayi \& Keluarga. Jakarta: ECG, 2011.p.363, 367, 372.

5. Ayesha HN, Nuryani, Astuti S. Efektivitas metode index card match dan ceramah dalam meningkatkan pengetahuan, sikap dan perilaku personal hygiene saat menstruasi remaja. 
Jurnal Kebidanan. Tunas-Tunas Riset Kesehatan. 2017; 7 (2)

6. Fitriani S. Promosi Kesehatan. Yogyakarta: Graha Ilmu, 2011. p. 64-70.

7. Sumiyati. Gambaran pengetahuan remaja putri tentang keputihan di Komplek $\mathrm{R} 1$ Pondok Pesantrenal-Munawwir Krapyak Bantul Yogyakarta. Jurnal Ilmu Kesehatan. 2017;1(1): 2.

8. Izzati, Agustiani WR. Hubungan pengetahuan dengan pelaksanaan personal hygiene genitalia saat menstruasi pada remaja putri Kelas IX SMP Negeri 4 Bukittinggi. Jurnal Ilmu Kesehatan 'Afiyah'. 2015; 2(1).

9. Silberman. Active Learning: 101 Cara Belajar Peserta Didik Aktif. Bandung: Nuansa Cendikia, 2011. p.115-121.

10. Ngestiningrum, Ayesha H. Perbandingan antara pengaruh layanan informasi dan konseling kelompok terhadap sikap tentang kesehatan reproduksi remaja. Jurnal Forikes.2010; 1(1): 7-15.

11. Nursalam. Metodologi Penelitian IImu Keperawatan: Pendekatan Praktis. 2011. Edisi 4.
Jakarta: Salemba Medika.

12. Notoatmodjo S. Promosi Kesehatan dan Perilaku Kesehatan. 2012. Jakarta: PT Rineka Cipta.

13. Sulistianingsih, Yanti, Karani. Upaya meningkatkan kebersihan genitalia remaja putri untuk mencegah kejadian flour albus di SMA dalam Muhammadiyah Kaliejo Lampung Tengah. Gaster. Jurnal Kesehatan. 2016; 14(2):17-25.

14. Nurharjanti, Pinki. Pengaruh pendidikan kesehatan tentang kehamilan resiko tinggi dengan metode index card match terhadap pengetahuan ibu hamil di Desa Gonilan Kartasura. Skripsi. Surakarta: Universitas Muhammadiyah Surakarta; 2019.

15. Sholikah, Anik, Widiastuti T. Hubungan penggunaan pembersih genitalia eksterna dengan kejadian keputihan pada siswi kelas X1 IPA Di Sman 1 MayongJepara. Jurnal Kesehatan Budaya. 2012; 3 (1):8-14.

16. Abrori, Dwi HA, Ermulyadi. Faktor yang berhubungandengankejadiankeputihan patologis siswi SMAN 1 Simpang Hilir Kabupaten Kayong Utara. Unnes Journal of Public Health. 2017; 6(1) 